DOI: $10.19195 / 0080-3626.60 .4$

ANNA TOKARSKA

\title{
POWOJENNY DOROBEK POLSKIEJ NAUKI W ZAKRESIE HISTORII I TEORII BIBLIOTEKOZNAWSTWA
}

Powojenne teorie bibliotekoznawstwa jako nauki, wybrane autorskie koncepcje i kierunki badawcze. Wpływ powojennych koncepcji bibliotekoznawstwa na zmiany wizerunku bibliotek i ewolucję akademickiego programu kształcenia bibliotekarzy. Dorobek piśmienniczy dyscypliny i jego rola w kształceniu.

SŁOWA KLUCZOWE: bibliotekoznawstwo, teoria bibliotekoznawstwa, historia bibliotekoznawstwa, bibliotekarstwo, akademickie kształcenie bibliotekarzy

Teoria i praktyczne rozwiązania w zakresie polskiego bibliotekoznawstwa w pewnej mierze nawiązują, a niejednokrotnie wynikają z niewątpliwych osiągnięć okresu II Rzeczypospolitej oraz rozpoczętych w tym czasie prac i dyskusji dotyczących kształtowania polityki bibliotecznej w niepodległej Polsce. Pomimo braku kompletu rozporządzeń prawnych, a przede wszystkim standaryzacji ustawowej, mimo opracowanych projektów, należy podkreślić duże znaczenie podejmowanych działań inicjujących rozwój teoretycznych podstaw bibliotekoznawstwa, a także uporządkowanie i standaryzację wielu kwestii organizacyjnych, w tym dotyczących funkcjonowania bibliotek i kształcenia kadry ${ }^{1}$. Ogromną rolę w procesie kształtowania nowoczesnego bibliotekoznawstwa i bibliotekarstwa odgrywała Biblioteka Narodowa (powstała 24 lutego 1928 roku). Podkreślić też należy znaczenie intensywnej działalności Związku Bibliotekarzy Polskich (od 1917, obecnie Stowarzyszenie Bibliotekarzy Polskich), rolę „Przeglądu Bibliotecznego” (Kraków 1927-), opracowanie pierwszych podręczników, instrukcji i norm bibliotekarskich, a także koncepcji dyscypliny. Systematyczne wprowadzanie zmian w wielu obszarach bibliotekoznawstwa i bibliotekarstwa możliwe było również dzięki zaangażowaniu i staraniom znakomitego grona praktyków i teoretyków

${ }^{1}$ Zofia GACA-DĄBROWSKA, Bibliotekarstwo II Rzeczypospolitej. Zarys problemów organizacyjnych i badawczych, wyd. 1, Wrocław: Wydaw. Uniwersytetu Wrocławskiego 1983; wyd. 2, Warszawa: Wydaw. SBP 2007. 
w ramach dyskusji i polemik, podczas zjazdów i konferencji, a także dzięki organizowaniu różnych form kształcenia bibliotekarzy.

Nową jakość, perspektywę badawczą i warunki rozwoju owe przedwojenne koncepcje i rozwiązania praktyczne w zakresie bibliotekoznawstwa i bibliotekarstwa uzyskały po wydaniu dekretu o bibliotekach i opiece nad zbiorami bibliotecznymi (17 kwietnia 1946 roku), a cezury czasowe faz ich rozwoju w pewniej mierze wynikały oraz wpływały na nowelizowanie kolejnych aktów prawnych — ustawy o bibliotekach z 9 kwietnia 1968 oraz 27 czerwca 1997 roku.

Próba syntezy powojennego dorobku w zakresie teorii i historii bibliotekoznawstwa, a zatem opracowanych koncepcji i rozwiązań praktycznych dotyczących biblioteki jako instytucji (,znawstwa biblioteki”), jest wyzwaniem dla badacza i zarazem recenzenta, gdyż z konieczności może być próbą ukazania głównych kierunków badawczych i rejestrem nadal toczących się dyskusji nad zakresem dyscypliny. Najważniejsze, konieczne do prezentacji zagadnienia dotyczą ich stanu, funkcji i misji, typologii i kultury organizacyjnej, stopnia i jakości realizowania procesów bibliotecznych oraz problemów standaryzacji, także zawodowej, a zatem również polityki i perspektyw zmian kształcenia bibliotekoznawców i bibliotekarzy, przede wszystkim na poziomie akademickim.

Bibliotekoznawstwo definiowane jest obecnie jako dyscyplina naukowa należąca do nauk społecznych, zajmująca się badaniem bibliotek jako określonego systemu komunikacji społecznej oraz roli tego systemu w szeroko pojętej kultu$\mathrm{rze}^{2}$. W ujęciu historycznym zagadnienia te były przedmiotem licznych dyskusji, opinii i rozważań, począwszy od Krótkiego rysu zasad bibliotekoznawstwa Włodzimierza Górskiego (Warszawa 1862), poprzez koncepcje Józefa Grycza i Leona Bykowskiego w okresie dwudziestolecia międzywojennego ${ }^{3}$, wczesne powojenne, zainicjowane najczęściej przed 1945 rokiem koncepcje twórców polskiego bibliotekoznawstwa: Adama Łysakowskiego, Stefana Vrtela-Wierczyńskiego i późniejszego współredaktora Encyklopedii wiedzy o ksiażce - Aleksandra Birkenmajera $^{4}$, Jana Muszkowskiego i Karola Głombiowskiego, po nowoczesne koncepcje Heleny Więckowskiej, Zofii Gacy-Dąbrowskiej, Jerzego Ratajewskiego, Barbary Sordylowej oraz Jacka Wojciechowskiego ${ }^{5}$.

2 Podręczny stownik bibliotekarza. Oprac. Grzegorz Czapnik, Zbigniew Gruszka przy współpracy Hanny Tadeusiewicz, Warszawa: Wydaw. SBP 2011, s. 43.

3 Z. GACA-DĄBROWSKA, op. cit., s. 131-132; Krzysztof MIGOŃ, Leon Bykowski (18951992) - ukraiński bibliolog i polski bibliotekarz, Roczniki Biblioteczne (47) 2003, s. 155-168.

${ }^{4}$ Bibliotekarstwo naukowe. Red. Adam Łysakowski, Warszawa: Państwowe Wydawnictwo Naukowe 1956; Adam ŁYSAKOWSKI, Katalog przedmiotowy. Teoria, Wilno 1928, reed. Warszawa: Wydaw. SBP 2002; Stefan VRTEL-WIERCZYŃSKI, Teoria bibliografii w zarysie, Wrocław: Wydaw. Zakładu Narod. im. Ossolińskich 1951; Aleksander BIRKENMAJER, Studia bibliologiczne. Wybór tekstów pod red. Heleny Więckowskiej i Aleksandry Birkenmajer, Wrocław: Zakład Narod. im. Ossolińskich 1975.

5 Zagadnienia historyczne analizował m.in. Jerzy Ratajewski, zob. Wprowadzenie do bibliotekoznawstwa czyli Wiedza o bibliotece w różnych dawkach. Do druku przygotował Zbigniew 


\section{K. Głombiowski pisał, iż}

Myśl wyodrębnienia spośród zjawisk kultury zespołu zagadnień związanych z książką i jej główną od wieków zbiornicą — biblioteką — nie jest zupełnie nowa, ani też zupełnie pozbawiona racji [...]. Problem biblioteki, to $\mathrm{z}$ dzisiejszego punktu widzenia przede wszystkim problem pośrednictwa książki, gdzie pytamy, jaką książkę i w jaki sposób biblioteka podsuwa określonemu czytelnikowi. Tu należą także wszystkie zagadnienia służby informacyjnej, a więc także bibliografii [...]. Alternatywę, czy książka istnieje dzięki bibliotece, czy też warunkiem istnienia biblioteki jest istnienie książki, rozstrzygniemy chyba bez trudu na korzyść pierwszeństwa i nadrzędności książki [...]. Dyscypliny nie stanowi tzw. nauka o bibliotece, której problematyka naukowa jest jeszcze za mało rozbudowana, aby mogła stanowić odrębną dyscyplinę uniwersytecką, może nią być natomiast nauka o książce, w której poważną cząstką jej żywej substancji badawczej jest również biblioteka $[\ldots]^{6}$.

W jego ocenie „nauka o książce jest dyscypliną badawczą, która zapewnia jeśli nie jedyną to najlepszą podstawę teoretyczną do działalności bibliotecznego aparatu rozprowadzania książki”.

Odrębne stanowisko - traktowanie bibliotekoznawstwa jako „dyscypliny węzłowej” - prezentowali Krystyna Remerowa, Władysław Piasecki oraz Helena Więckowska ${ }^{7}$. W kształtującej się powojennej rzeczywistości, aż do początku lat 70., bibliotekoznawstwo jako dyscyplina należało zatem według wielu badaczy do bibliologii, czego dowodem jest definicja zamieszczona w Encyklopedii wiedzy $o$ książce, zgodnie z którą bibliotekoznawstwo to

jeden z działów nauki o książce, poświęcony badaniom biblioteki jako określonej instytucji naukowej i społeczno-oświatowej w aspekcie historycznym i organizacyjnym. Należą tu takie przedmioty jak: dzieje bibliotek, organizacja i typologia bibliotek $\mathrm{i}$ ich odmiennie realizowane funkcje społeczne oraz bibliotekarstwo [...] w zespole dyscyplin tworzących bibliologię bibliotekoznawstwo zajmuje określone miejsce, równoległe do historii książki, bibliografii i teorii czytelnictwa. W schemacie klasyfikacyjnym przyjmującym podział według głównych problemów bibliologii, tj. wytwarzania, pośrednictwa i konsumpcji książki bibliotekoznawstwo mieści się w problematyce pośrednictwa (w tym zestawieniu wraz z bibliografią i księgarstwem) $[\ldots]^{8}$.

Żmigrodzki przy współpr. Elżbiety Gondek. Warszawa: Wydaw. SBP 2012; a także Elżbieta GONDEK, Bibliotekarstwo a bibliotekoznawstwo, bibliologia i informatologia, [w:] Bibliotekarstwo. Red. Anna Tokarska, Warszawa: SBP 2013, s. 102-114.

${ }^{6}$ Karol GŁOMBIOWSKI, Bibliotekoznawstwo jako dyscyplina uniwersytecka, Roczniki Biblioteczne (6) 1962, s. 1-19.

${ }^{7}$ Krystyna REMEROWA, Władysław SKOCZYLAS, W sprawie szkolenia bibliotecznych kadr naukowych, Przegląd Biblioteczny (21) 1953, z. 4, s. 297-325; K. REMEROWA, Zmiany funkcji bibliotek $w$ powojennym dwudziestoleciu, Warszawa: SBP 1966; Władysław PIASECKI, Zwięzty wstęp do bibliotekoznawstwa, Kraków: AGH 1968 (wyd. 21968 tamże); H. WIĘCKOWSKA, Bibliotekoznawstwo polskie. Przeszłość, stan obecny, perspektywy rozwoju. Referat na II Kongres Nauki Polskiej. Z materiałów Podsekcji Informacji i Dokumentacji Naukowej, Przegląd Biblioteczny (41) 1973, z. 3, s. 259-277.

${ }^{8}$ Encyklopedia wiedzy o ksiażce. Red. Aleksander Birkenmajer, Bronisław Kocowski, Jan Trzynadlowski, Wrocław [i in.]: Zakład Narod. im. Ossolińskich 1971, szp. 302-303; 1589-1590. 
Zgodnie z zapisem w późniejszej Encyklopedii współczesnego bibliotekarstwa polskiego „bibliotekoznawstwo to nauka poświęcona badaniom biblioteki, jednego z podstawowych elementów w procesie gromadzenia, społecznego rozprowadzania i informacji o zawartości książki. Wchodzi w skład zespołu dyscyplin bibliologicznych badających procesy związane z powstawaniem, upowszechnianiem, użytkowaniem i recepcją czytelniczą książki [...]". Autorka definicji, H. Więckowska, zauważyła, iż ,nie doszło jeszcze u nas, podobnie jak za granicą, do całkowitego skrystalizowania pojęcia bibliotekoznawstwa jako dyscypliny naukowej i chociaż podzielone są zdania na temat jej stosunku do nauki o książce i stopnia jej samodzielności, to jednak dostrzega się już dziś wyraźnie kierunek rozwoju współczesnego bibliotekoznawstwa polskiego [...]"9. W innych swoich publikacjach Więckowska uzasadniała, że podobnie jak bibliografia,

wyodrębnia się również bibliotekoznawstwo, które w aspekcie historycznym i współczesnym bada funkcje społeczne bibliotek jako instytucji gromadzących, upowszechniających książki i rozprowadzających informacje o ich zawartości. [...] Przed tak pojętym bibliotekoznawstwem polskim otwierają się obecnie szerokie perspektywy badań skierowanych ku zagadnieniom modernizacji dzisiejszych bibliotek - ich struktury organizacyjnej, układów funkcjonalnych i metod pracy tak by mogły w należyty i racjonalny sposób korzystać z nowych technik, z mechanizacji i automatyzacji dla zaspokajania potrzeb społecznych ${ }^{10}$.

W konkluzji stwierdza, iż schemat klasyfikacyjny Jana Muszkowskiego ${ }^{11}$, „aczkolwiek bardzo przejrzysty i logiczny, wymaga już dziś pewnych modyfikacji ze względu na proces rozwojowy poszczególnych jego członów. Jedne z nich bowiem podlegają specjalizacji, inne integracji [..."’12. Autorka ukazała także nowoczesne postulaty badawcze: przewidywane kierunki dalszego rozwoju i zagadnienia priorytetowe w zakresie 1) zbiorów bibliotecznych (postuluje ochronę i zabezpieczenie przed zniszczeniem), 2) informacji o zasobach (,pełne ich ujawnienie", przede wszystkim zbiorów specjalnych), 3) unowocześnienia warsztatów bibliotecznych (mechanizacja), 4) wprowadzania nowych form organizacyjnych bibliotek uczelnianych, 5) budownictwa i wyposażenia, 6) ustawodawstwa i 7) współpracy międzybibliotecznej. Wśród postulatów dotyczących kadry naukowej znalazł się zapis o konieczności „powołania do życia” czwartego (po łódzkim, warszawskim i wrocławskim) Instytutu Bibliotekoznawstwa na Uni-

${ }^{9}$ Encyklopedia współczesnego bibliotekarstwa polskiego. Kom. Red. Karol Głombiowski, Bolesław Świderski, Helena Więckowska, Wrocław [i in.]: Zakład Narod. im. Ossolińskich 1976, s. $80-81$.

10 H. WIĘCKOWSKA, op. cit., s. 267; eadem, Organizacja, stan i kierunki badań bibliologicznych 1945-1967, Przegląd Biblioteczny (36) 1968, z. 1-2, s. 45-77.

11 Jan MUSZKOWSKI, Życie książki, Warszawa: „Nasza Księgarnia” 1936, wyd. 2 Kraków: Wiedza, Zawód, Kultura 1951; edycja krytyczna na podstawie wydania z 1951 r., Łódź: Uniwersytet Łódzki, SBP 2015. Badania bibliologiczne według autora obejmują trzy fazy rozwoju książki: produkcję, obieg i recepcję. W dziale obiegu znajduje się bibliotekoznawstwo, bibliografia i księgarstwo.

${ }^{12}$ H. WIĘCKOWSKA: Bibliotekoznawstwo polskie..., s. 265. 
wersytecie Jagiellońskim, z pełnymi studiami dziennymi i zaocznymi, oraz, dla zintensyfikowania badań, utworzenie naukowego, „nie biurokratycznego” ośrodka centralnego, nazwanego przez nią Instytutem Księgo- i Bibliotekoznawstwa na przykład w ramach Polskiej Akademii Nauk.

W połowie lat 70. zauważyć można niewątpliwy rozwój dyscypliny, a oprócz funkcjonującej już od 1945 roku pierwszej Katedry Bibliotekoznawstwa i Informacji Naukowej w Lodzi, katedr bibliotekoznawstwa w Warszawie (1951) i Wrocławiu (1956) zorganizowano kolejne ośrodki kształcenia akademickiego: w Bydgoszczy i krakowskiej Wyższej Szkole Pedagogicznej (obecnie Uniwersytet Pedagogiczny, 1971) i, początkowo jako zakłady, w instytutach filologii polskiej w Uniwersytecie Jagiellońskim, lubelskim Uniwersytecie Marii Curie-Skłodowskiej i w Uniwersytecie Śląskim (1974), Kielcach (1975/76) oraz Toruniu (1976).

Od wczesnych lat 80 . XX wieku bibliotekoznawstwo stało się samodzielną dyscypliną naukową, „mającą własne pola badawcze, które tylko w części są wspólne z bibliologią [..."13. Uzyskanie przez dyscyplinę autonomii pozwoliło na dalszy, intensywny rozwój teorii i metodologii badawczej, widoczny w koncepcjach Zofii Gacy-Dąbrowskiej i Jerzego Ratajewskiego oraz pracach Barbary Sordylowej, która analizowała już wzajemne relacje pomiędzy informacją naukową, bibliologią a bibliotekoznawstwem ${ }^{14}$.

Zofia Gaca-Dąbrowska w koncepcji dyscypliny, określonej jako „nauka o bibliotece" wyodrębniła sześć pól badawczych: 1) zagadnienia ogólne (normalizacja terminologiczna i bibliotekarska, klasyfikacja i typologia bibliotek); 2) biblioteka w społeczeństwie (społeczne znaczenie bibliotek i ich rola w komunikacji i systemach rozpowszechniania informacji, propaganda biblioteczna, pedagogika biblioteczna i prawo biblioteczne); 3) procesy biblioteczne i ich organizacja (gromadzenie, opracowanie, użytkowanie); 4) systemy biblioteczne (tu także zasady polityki bibliotecznej w kraju); 5) zawód bibliotekarza (pragmatyka, kształcenie, socjologia i warsztat zawodowy bibliotekarza, ranga zawodu); 6) środki warunkujące działalność bibliotek (budownictwo, wyposażenie, finanse) ${ }^{15}$. Duże znaczenie w tej koncepcji miało wyodrębnienie społecznej funkcji biblioteki i roli bibliotek w „masowej komunikacji”, dostrzeżenie wagi spraw związanych z zawodem bibliotekarza, a także „fizycznością” biblioteki, m.in. zasadą funkcjonalności w budownictwie i estetyką wnętrz.

Jerzy Ratajewski w licznych pracach analizował zagadnienia bibliotekoznawstwa w relacji z innymi naukami, a zwłaszcza problem ich obecności wśród nauk ścisłych lub społecznych. Przywołując dwie perspektywy badawcze i odmienne

13 K. MIGOŃ, Nauka o książce. Zarys problematyki, Wrocław: Zakład Narod. im. Ossolińskich 1984, s. 203.

14 Barbara SORDYLOWA, Wzajemne relacje pomiędzy dyscyplinami: informacja naukowa, bibliologia, bibliotekoznawstwo, Przegląd Biblioteczny (57) 1989, z. 4, s. 309-315.

15 Z. GACA-DĄBROWSKA, O teoretycznych problemach nauki o bibliotece, Studia o Książce (10) 1980, s. 201-209; zob. też E. GONDEK, op. cit. 
poglądy na bibliotekoznawstwo - jako naukę stosowaną (praktykę optymalnego działania) lub jako uznaną także za naukę teoretyczną — stwierdza:

Sądzę, iż można oba stanowiska pogodzić, uznając bibliotekoznawstwo za dyscyplinę naukową o charakterze kompleksowym (interdyscyplinarnym) [...]. Bibliotekoznawstwo to nauka kompleksowa o bibliotece i procesach bibliotecznych, traktująca bibliotekę jako system społeczno-techniczny (socjotechniczny), badająca i ustalająca historyczne, współczesne i przyszłe funkcje społeczne biblioteki w społeczeństwie $[\ldots]^{16}$.

Bibliotekoznawstwo jako nauka interdyscyplinarna (kompleksowa) ma równocześnie charakter nauki teoretycznej (podstawowej, gdyż ustala sens istnienia i historię biblioteki jako systemu oraz prawidłowości jej działania), stosowanej (ustala wskazówki dla realizacji procesów i ich rozwoju), normatywnej (ustala normy i reguły sprawnego działania biblioteki). W koncepcji „biblioteki jako systemu"17, a bibliotekoznawstwa jako kompleksu nauk wyróżnił: 1) teorię bibliotekoznawstwa; 2) procesy biblioteczne (gromadzenie, opracowanie i wyszukiwanie, udostępnianie); 3) metodologię bibliotekoznawstwa; 4) działy bibliotekoznawstwa - począwszy od filozofii, historii, socjologii i psychologii bibliotek, poprzez pedagogikę i marketing, ekonomikę, politykę, etykę, prakseologię do informologii biblioteki.

Włączenie przez J. Ratajewskiego w zakres bibliotekoznawstwa informologii było charakterystycznym znakiem zmiany dokonującej się w tym czasie — stopniowego łączenia bibliotekoznawstwa i informacji naukowej, a od początku XXI wieku eksponowania zadań informacyjnych. Barbara Sordylowa pisała: „Przedmiotem zarówno bibliotekoznawstwa, jak i informacji naukowej są infrastruktura biblioteczna i informacyjno-komunikacyjna widziane w skali makro - jako krajowy system biblioteczny tudzież krajowy system informacyjny, oraz w skali mikro - jako system konkretnej biblioteki, ośrodka informacji, archiwum czy innej placówki informacyjnej [...]"18. Znamienna była wprowadzona w latach 1991-2004 modyfikacja nazw wielu instytutów bibliotekoznawstwa z wyeksponowaniem informacji naukowej na pierwszym miejscu (Wyższa Szkoła Pedagogiczna w Krakowie, Uniwersytet Jagielloński, Uniwersytet Marii Curie-Skłodowskiej, Uniwersytet Mikołaja Kopernika, Uniwersytet Wrocławski). W ośrodku warszaw-

16 J. RATAJEWSKI, op. cit., s. 192-193; idem, Drugi raz o bibliotekoznawstwie. Rozważania metodologiczne, Roczniki Biblioteczne (28) 1984, z. 1-2, s. 231-252; idem, Trzeci raz o bibliotekoznawstwie. Rozważanie metodologiczne, Roczniki Biblioteczne (30) 1986, z. 1-2, s. 379-395; idem, Biblioteki, bibliotekarstwo, bibliotekoznawstwo, [w:] Bibliotekarstwo, wyd. 2 uzup. Red. Z. Żmigrodzki, Warszawa: Wydaw. SBP 1998, s. 13-15.

17 Zgodnie z jego definicją: „Biblioteka jest to określony i zorganizowany według właściwych sobie zasad system komunikacji społecznej”. Zob. Biblioteki, bibliotekarstwo..., s. 14; por. Anna SITARSKA, Systemowe badanie bibliotek. Studium metodologiczne, Łódź: Wydaw. Uniwersytetu Łódzkiego 1990.

18 B. SORDYLOWA, op. cit., s. 313. 
skim i krakowskim wprowadzono i nadal konsekwentnie realizowano „matematyczny" profil studiów.

Modyfikacja koncepcji bibliotekoznawstwa jako „wiedzy [nauki] o bibliotekarstwie" widoczna jest w publikacjach Jacka Wojciechowskiego. Swoje stanowisko opiera na akcentowaniu mediacyjnej roli biblioteki, definiowanej jako „wielosemiotyczne medium komunikowania” w procesie pośrednictwa pomiędzy przekazami a ich odbiorcami. Wyodrębnia on pięć etapów umożliwiających pośredniczenie: 1) tworzenie i kodowanie przekazów; 2) przygotowanie przekazów do odbioru (od gromadzenia do indeksowania — katalogowania i bibliografowania); 3) organizowanie mediacji (zewnętrznej i wewnętrznej); 4) mediacja (udostępnianie zbiorów, podaż informacji, marketing i promocja, praca z użytkownikiem); 5) odbiór przekazów (tutaj także społeczne funkcje bibliotek, grupy odbiorców) ${ }^{19}$. Elżbieta Gondek pisze:

bibliotekoznawstwo jest nauką, która zrodziła się, potem ewaluowała w wyniku zmiennej organizacji oraz społecznych funkcji bibliotek i czynności bibliotekarskich [...]. Samodzielność czy niesamodzielność formalna bibliotekoznawstwa nie decyduje o problemach, jakie praktyka biblioteczna musi rozwiązać. Pragmatyzm celów, zadań i funkcji bibliotek nadal wymaga zgodności dostosowawczej praktyki (a więc też teorii i metod badań) do poziomu kultury w określonym miejscu i czasie $[\ldots]^{20}$.

W ostatnich latach, oprócz dominującego kierunku badań funkcjonowania bibliotek w systemie komunikacji społecznej (publicznej), uwzględniano także inne perspektywy badawcze, m.in. obecność biblioteki jako instytucji w systemie kultury, wizerunek biblioteki jako organizacji non profit wśród innych instytucji niedochodowych - w powiązaniu z zagadnieniami zarządzania zasobem, informacją oraz kadrą ${ }^{21}$, a także jako element polityki państwowej (narodowej). Interesujący kierunek badawczy wynika z obecności biblioteki w globalnej przestrzeni informacyjnej, z akcentowania jej zwiększającej się roli w organizowaniu informacji, także w przestrzeni wirtualnej. Perspektywa ta przyjęta została w Bibliotekarstwie pod red. Anny Tokarskiej (Warszawa 2013), a biblioteka definiowana jest jako element przestrzeni informacyjnej, co pozwala łączyć bibliotekoznawstwo i bibliotekarstwo z informacją naukową.

Obecne dyskusje na temat zmieniającego się wizerunku bibliotek i ich modelu w przyszłości widoczne są w publikacjach J. Wojciechowskiego ${ }^{22}$, Jadwigi Koło-

19 Jacek WOJCIECHOWSKI, Idee i rzeczywistość. Bibliotekarstwo pragmatyczne, Warszawa: Wydaw. SBP 2002; idem, Biblioteczna wartość naddana, Kraków: Wydaw. Uniwersytetu Jagiellońskiego 2006.

20 E. GONDEK, op. cit., s. 102-114.

21 Teresa WILKOŃ, Biblioteka w systemie kultury, [w:] Bibliotekarstwo..., s. 90-101; Zarzadzanie marketingiem w organizacjach niedochodowych. Red. Andrzej Chodyński, Marian Huczek, Irena Socha, Sosnowiec: Wydaw. Wyższej Szkoły Zarządzania i Marketingu 2002.

22 J. WOJCIECHOWSKI, Bibliotekarstwo. Kontynuacje i zmiany, Kraków: Wydaw. Uniwersytetu Jagiellońskiego 1999, 2001; idem, Biblioteczna wartość naddana ...; idem, Biblioteka w ko- 
dziejskiej, Ewy Głowackiej, Jana Wołosza, Elżbiety Barbary Zybert i wypowiedziach autorów w wielu pracach zbiorowych ${ }^{23}$. Znamienny tytuł Na rozstajach, rozpoczynający analizę J. Wojciechowskiego dotyczącą sytuacji bibliotek „w nowym otoczeniu", wydaje się symboliczną odpowiedzią na najważniejsze pytania dotyczące przyszłości bibliotek i bibliotekoznawstwa w Polsce, związane przede wszystkim z: 1) pośredniczeniem (m.in. różnorodność, poza komercją, publiczność); 2) usługami bibliotecznymi; 3) uczelnianą siecią biblioteczną i obszarami kooperacji bibliotek akademickich; 4) funkcjonowaniem bibliotek publicznych (biblioteczny uniwersalizm, środowiskowość, obszary oferty); 5) odbiorem komunikatów z Internetu i z druku (koegzystencja) ${ }^{24}$. Podejmowane próby prognozowania dotyczące przyszłości polskiego bibliotekarstwa są przede wszystkim dowodem na konieczność systematycznego rozwoju umiejętności zawodowych bibliotekarzy, w tym tworzenia elektronicznych instrukcji i kształcenia użytkowników na odległość, konieczność tworzenia infrastruktury naukowej we współpracy bibliotekarzy i naukowców. W dalszej kolejności prognozowany jest rozwój atrakcyjnych form akcji bibliotecznych i wydarzeń rozrywkowych wynikający z oczekiwań odbiorców, systematyczny wzrost digitalizacji zasobów, a centrum działań bibliotecznych ,przesunie się z tworzenia i zarządzania zbiorami w kierunku projektowania i dostarczania usług". Niezwykle interesujący jest wniosek (ok. 15\% prawdopodobieństwa), z którego wynika, iż „wzrośnie rola takich grup odbiorców bibliotek, jak emigranci, seniorzy, wyznawcy różnych religii. Oferta skierowana do nich stanie się częścią kanonu usług, promowanych w ramach standardowych działań marketingowych czy PR”. Ostatnie miejsce (3,7 \% prawdopodobieństwa) zajmuje prognozowanie wzrostu roli środków prywatnych w budżetach bibliotek

munikacji publicznej, Warszawa: Wydaw. SBP 2010; idem, O bibliotekach po mojemu, Warszawa: Wydaw. SBP 2012; idem, Biblioteki w nowym otoczeniu, Warszawa: Wydaw. SBP 2014.

23 Jadwiga KOŁODZIEJSKA, Między tradycyjnością a nowoczesnością bibliotek, Przegląd Biblioteczny 2011, z. 2, s. 179-191; Jan WOŁOSZ, Meandry polskiego bibliotekarstwa 19912011, Warszawa: Wydaw. SBP 2012; David NICHOLAS, Zdzisław DOBROWOLSKI, O przyszłości bibliotek, Przegląd Biblioteczny 2012, z. 4, s. 521-525. Prace zbiorowe: Biblioteki wobec nowych zadań. Red. Ewa Głowacka, Toruń: Wydaw. UMK 2004; Przyszłość bibliotek w Polsce. Materiały z ogólnopolskiej konferencji, Warszawa 12-13.10.2007, Warszawa: Wydaw. SBP 2008; Nowoczesna biblioteka. Materiały z ogólnopolskiej, przedzjazdowej konferencji SBP Konstancin-Jeziorna, 29-30 maja 2009, Warszawa: Wydaw. SBP 2009; Bibliologia, biblioteki, bibliotekarze. Red. Dariusz Grygrowski, Elżbieta B. Zybert, Warszawa: Wydaw. SBP 2005; zob. też prace Zakładu Bibliotekoznawstwa Instytutu Informacji Naukowej i Studiów Bibliologicznych Uniwersytetu Warszawskiego (obecnie Katedra Badań nad Bibliotekami i Innymi Instytucjami Kultury na Wydziale Dziennikarstwa, Informacji i Bibliologii UW): Biblioteki, tożsamość, kultura. Red. Iwona H. Pugacewicz, Elżbieta Barbara Zybert, Warszawa: Wydaw. SBP 2013; Megabiblioteki. Wybrane tendencje w bibliotekarstwie publicznym. Red. Dorota Pietrzkiewicz, Elżbieta Barbara Zybert, Warszawa: Wydaw. SBP 2015.

24 J. WOJCIECHOWSKI, Biblioteki w nowym otoczeniu..., s. 13-52 n.

Roczniki Biblioteczne 60, 2016

(C) for this edition by CNS 
i „współpracy organizacji biznesowych z bibliotekami na zasadach partnerstwa, dotacji, sponsoringu czy filantropii" 25 .

Próba analizy dorobku z zakresu bibliotekoznawstwa w Polsce może przyjąć różnorodny porządek, wynikający m.in. z charakterystycznych zadań (funkcji) bibliotek oraz ich misji, zatem zasadę „drogi książki”, począwszy od polityki gromadzenia zasobu do oferty usług i działań informacyjnych. Może przyjąć również porządek zgodny z typologią bibliotek wynikającą z postanowień obowiązującej ustawy o bibliotekach. W obszarze badań i refleksji znajdą się wówczas zagadnienia bibliotek naukowych, publicznych, szkolnych i pedagogicznych oraz fachowych i zakładowych. Zdaniem Krzysztofa Migonia nieodłączną częścią problematyki współczesnego bibliotekoznawstwa jest także historia bibliotek i bibliotekarstwa ${ }^{26}$, lecz zagadnienia te wymagają odrębnej, szczegółowej analizy kierunków badawczych oraz publikacji wydanych w poszczególnych ośrodkach, prezentujących historię bibliotek w Polsce na tle europejskim i światowym. Najpełniej jednak tematyka bibliotekoznawcza, obecna w polskim piśmiennictwie naukowym w wydawnictwach zwartych i ciągłych zostanie przeanalizowana, począwszy od podstaw wiedzy o bibliotece (w tym prawa bibliotecznego), poprzez organizację i zarządzanie zasobami, organizowanie informacji i dostępu do informacji, ofertę usług bibliotecznych oraz grona ich odbiorców, do zarządzania biblioteką i jej wizerunkiem (budownictwo biblioteczne, design i aranżacja wnętrz). Podobny układ został zaproponowany w Bibliotekarstwie (2013).

Piśmiennictwo dotyczące bibliotekoznawstwa i bibliotekarstwa, w tym diagnoza polityki bibliotecznej państwa, analiza kultury organizacyjnej i funkcjonowania poszczególnych typów bibliotek, ma duże znaczenie edukacyjne i użytkowe dla bibliotekarzy praktyków. Podobnie istotne było wydanie encyklopedii i słowników, kolejnych podręczników z zakresu bibliotekarstwa, syntez i kompendiów. Te niewątpliwe osiągnięcia edytorskie można analizować, przyjmując jako cezury czasowe ukazujące się kolejne akty prawne, uporządkowujące zagadnienia dotyczące bibliotek (dekret z 1946 roku, ustawy o bibliotekach z 1968 i 1997 roku), a także rozbudowaną dokumentację w sprawie bibliotek i bibliotekarstwa. Dużą ich grupę stanowią dokumenty wyznaczające kierunki badawcze i perspektywę rozwoju bibliotek w Polsce: Materiaty z Konferencji Rogowskiej w sprawie działalności i rozwoju bibliotek (Warszawa 1962), „Program rozwoju bibliotekarstwa polskiego do 1990 roku” (Poznań 1978), „Raport o stanie bibliotek polskich” (Warszawa 1973, wyd. 2 tamże 1974); „Raport o stanie bibliotek resortu oświaty i wychowania” (Warszawa 1980); wreszcie „Stan i perspektywy bibliotekarstwa polskiego do roku 2000” (Warszawa 1987). Istotne znaczenie dla kształtowania

${ }^{25}$ Zob. Ocena prawdopodobieństwa prognoz dotyczacych przyszłości bibliotekarstwa w Polsce, [w:] Nowoczesna biblioteka..., s. 96-97.

${ }^{26}$ K. MIGOŃ, O wspótczesnej sytuacji badawczej w naukach o książce, bibliotece i informacji, [w:] Przyszłość bibliotek w Polsce..., s. 71. 
polityki bibliotecznej w Polsce miał „Plan specjalizacji bibliotek” z 26 kwietnia 1979 roku, a także idea programu SINTO, rozporządzenia w sprawie Narodowego Zasobu Bibliotecznego (1998, 2012), polityka archiwizowania, ochrony i konserwacji zasobów, zwłaszcza księgozbiorów historycznych jako dóbr kultury, planowa i systematyczna digitalizacja kolekcji. Ważną rolę w podkreślaniu obecności bibliotek w budowaniu społeczeństwa informacyjnego spełniają ogólnopolskie programy biblioteczne Biblioteka 2.0 (3.0, Second Life), Interklasa, Biblioteka+ Program Rozwoju Bibliotek. Wiele działań bibliotekarskich jest efektem dokumentacji opracowywanej w Bibliotece Narodowej — informatorów i wykazów bibliotek oraz ośrodków informacji naukowej ${ }^{27}$, sprawozdań, serii oraz wydawnictw instytutów, zakładów i działów, przekładów literatury zagranicznej (Zeszyty Przekładów).

Przyjęta systematyka zagadnień z zakresu bibliotekoznawstwa i bibliotekarstwa widoczna jest w podręcznikach akademickich. Rolę taką miało fundamentalne Bibliotekarstwo naukowe z uwzględnieniem dokumentacji technicznej pod red. A. Łysakowskiego (Warszawa 1956), synteza Ewy Pawlikowskiej — Bibliotekarstwo powszechne (Warszawa 1957-1959), funkcję podręcznika akademickiego przyjęło również Bibliotekarstwo wydane z inicjatywy Zbigniewa Żmigrodzkiego (1994, przy współudziale J. Ratajewskiego i A. Tokarskiej; 2. wyd. 1998) oraz wydanie najnowsze (2013), do którego zaproszenie przyjęło grono bibliotekarzy, teoretyków i specjalistów z wielu ośrodków.

Po 1945 roku wydawano także liczne publikacje ogólne i podręcznikowe z zakresu bibliotekoznawstwa, kompendia, skrypty uniwersyteckie, wydawnictwa konferencyjne, materiały metodyczne, a także „wybory tekstów”, „przewodniki” oraz „materiały do studiowania”, m.in. opracowane przez Z. Gacę-Dąbrowską i Annę Aleksiewicz (Wrocław), Adama Jarosza i Henryka Kota oraz zespół pod kierunkiem J. Ratajewskiego (Katowice) ${ }^{28}$. Duże znaczenie edukacyjne miała publikacja Biblioteki współczesne. Bibliografia. Informacja naukowa Henryka Sawoniaka (Katowice 1995) oraz wydawnictwa typu Vademecum bibliotekarza redagowane przez Lucjana Bilińskiego (Warszawa 2006), a także oczekiwany Podręczny stownik bibliotekarza i pracownika informacji (Warszawa 2011). Pra-

27 Irena KLIMOWICZOWA, Ewa SUCHODOLSKA, Informator o bibliotekach $i$ ośrodkach informacji naukowej w Polsce, Warszawa: Biblioteka Narodowa 1973.

28 Przewodnik metodyczny do nauki przedmiotu Bibliotekarstwo. Oprac. Anna Aleksiewicz, Z. Gaca-Dąbrowska, Wrocław: Wydaw. Uniwersytetu Wrocławskiego 1976, 1978; Bibliotekarstwo. Materiały pomocnicze do nauki przedmiotu. Wybór tekstów i oprac. Z. Gaca-Dąbrowska, Wrocław: Wydaw. Uniwersytetu Wrocławskiego 1980, 1983; Materiały do studiowania bibliotekoznawstwa i informacji naukowej. Red. Adam Jarosz, Henryk Kot, Katowice: Uniwersytet Śląski 1980; Wanda KOCHMAŃSKA, Krystyna PUZIO, J. RATAJEWSKI, Biblioteka. Cz. 1. Organizacja biblioteki, gromadzenie i opracowanie zbiorów bibliotecznych, Katowice: Uniwersytet Śląski 1976, 2. wyd. 1979; Cz. 2. Udostępnianie zbiorów i działalność informacyjna, Katowice: Uniwersytet Śląski 1978. 
wo biblioteczne, kolejne rozporządzenia i nowelizacje, systematycznie prezentuje środowisku Tadeusz Zarzębski i Bolesław Howorka, a zagadnienia te w kontekście europejskim są przedmiotem badań Diany Pietruch-Reizes ${ }^{29}$. Ważna dla prac bibliotekarskich wiedza o normalizacji bibliotecznej i obowiązujących standardach jest dostępna dzięki publikacjom redagowanym przez J. Wołosza i Maję Wojciechowską ${ }^{30}$. Należy też wspomnieć o pewnych aspektach polityki bibliotecznej (wyodrębnionej w teorii J. Ratajewskiego), obecnych m.in. w publikacjach redagowanych przez Dariusza Kuźminę ${ }^{31}$.

Organizowanie zasobów, zatem zagadnienia profilowania zbiorów (tradycyjnych i cyfrowych), zarządzania kolekcją, finansowania (fundrasing, sponsoring) obecne w pracach Artura Jazdona, Dariusza Grygrowskiego, w pracach zbiorowych $^{32}$, wynikają ze sprawnych działań bibliotekarskich. Zagadnienia te prezentował J. Wojciechowski oraz Elżbieta Barbara Zybert ${ }^{33}$. W ostatnich latach dużo z podejmowanych badań dotyczy planowej i systematycznej digitalizacji zasobów, organizowania bibliotek cyfrowych, a także programów oraz metod ochrony i konserwacji różnych typów dokumentów, m.in. zgodnie z planem Narodowego Zasobu Bibliotecznego (1998, 2012).

Organizowanie informacji należy do najważniejszych zadań bibliotek, a jej kodowanie i transmisja powinny wynikać z potrzeb i oczekiwań odbiorców klientów i prosumentów informacji. Publikacje z tego zakresu, podręczniki, syntezy oraz normy dotyczące zasad redagowania opisu dokumentów według ISBD, klasyfikowania zgodnie z UKD oraz wprowadzania języka haseł przedmiotowych (JHP BN, KABA) należą do grupy najliczniejszych i najczęściej aktualizowanych przez ich autorów. Zagadnienia klasyfikowania zbiorów podejmowali: Eugeniusz Ścibor, Olgierd Ungurian, autorką nowoczesnych podręczników z tego zakresu

29 Tadeusz ZARZĘBSKI, Bolesław HOWORKA, Bibliotekarz i prawo. Podstawowe informacje dla pracowników bibliotek, Warszawa: Wydaw. SBP 2010; Diana PIERUCH-REIZES, Biblioteka i informacja w systemie parlamentarnym Unii Europejskiej i Rady Europy. Od historii do wspótczesności, Katowice: Wydaw. Uniwersytetu Śląskiego 2005; eadem, Podstawy prawne funkcjonowania bibliotek i działalności informacyjnej, [w:] Bibliotekarstwo..., s. 32-65.

30 Standardy biblioteczne. Wzorce i doświadczenia Unii Europejskiej. Red. J. Wołosz, Warszawa: Wydaw. SBP 2003; Standardy biblioteczne, Praktyka, teoria, projekty. Red. Maja Wojciechowska, Gdańsk: Wydaw. Ateneum 2010.

31 Bibliologia i informatologia, Warszawa: Polskie Tow. Bibliologiczne 2011; Bibliologia polityczna, Warszawa: Wydaw. SBP 2011; Bibliologia. Problemy badawcze nauk humanistycznych, Warszawa: Wydaw. SBP 2007.

32 Artur JAZDON, Zarzadzanie finansami i pozyskiwanie funduszy, [w:] Bibliotekarstwo..., s. 606-618; D. GRYGROWSKI, Biblioteki i pieniadze, Warszawa: Wydaw. SBP 2015; Finanse w bibliotece, Biuletyn EBIB 2009, nr 8; Grażyna TETELA, Polityka gromadzenia i selekcja zbiorów, [w:] Bibliotekarstwo..., s. 131-142.

33 J. WOJCIECHOWSKI, Organizacja i zarzadzanie w bibliotekach, Warszawa: Wydaw. Naukowe PWN 1997, 1998; E.B. ZYBERT, Kultura organizacyjna w bibliotekach. Nowe i stare idee w zarzadzaniu biblioteka, Warszawa: Wydaw. SBP 2004. 
jest Barbara Sosińska-Kalata ${ }^{34}$. Problematykę katalogowania przedmiotowego i języków tematowania, począwszy od twórcy katalogu przedmiotowego w Polsce - Adama Łysakowskiego - kontynuowali Jan Kossonoga, Jadwiga Ćwiekowa, a obecnie podejmują Jadwiga Sadowska, Jadwiga Czarnecka oraz Jadwiga Woźniak-Kasperek ${ }^{35}$.

Udostępnianie zasobów, informacji, przestrzeni bibliotecznej oraz zagadnienia oferty i jakości usług bibliotecznych ${ }^{36}$ podlegających ocenie ${ }^{37}$ łączy się z badaniem oczekiwań odbiorców informacji, stopnia ich satysfakcji oraz form i metod działalności informacyjnej. Wiele prac dotyczy zasad współpracy między bibliotekami a innymi instytucjami edukacji i kultury, marketingu i promowania bibliotek w środowisku.

Badania zachowań informacyjnych prowadzone są przez Annę Mierzecką-Szczepańską, Barbarę Kamińską-Czubałę ${ }^{38}$, natomiast zainteresowania Marzeny Świgoń koncentrujące się dotąd wokół zagadnień lęku przed biblioteką i barier informacyjnych obecnie dotyczą również zachowań informacyjnych ${ }^{39}$. M. Wojciechowska konsekwentnie prowadzi badania zarządzania zasobami niematerialnymi bibliotek ${ }^{40}$, ukazują się również analizy kadry bibliotecznej, rankingu cech,

34 Barbara SOSIŃSKA-KALATA, Klasyfikacja. Struktury organizacji wiedzy, piśmiennictwa i zasobów informacyjnych, Warszawa: Wydaw. SBP 2002; eadem, Podręcznik UKD dla bibliotekarzy i pracowników informacji, Warszawa: Wydaw. SBP 1993, 1995; eadem, Klasyfikacje biblioteczne i bibliograficzne i Uniwersalna Klasyfikacja Dziesiętna, [w:] Bibliotekarstwo..., s. 301-328, 329-355.

35 Jadwiga ĆWIEKOWA, Opracowanie tematyczne piśmiennictwa. Problemy teoretyczne i metodyczne, Warszawa: Prac. Repr. IN PAN 1974; Instrukcja tematowania i katalogu przedmiotowego. Oprac. Jadwiga Sadowska, Warszawa: SBP 1991; Jadwiga WOŹNIAK-KASPEREK, Wiedza i język informacyjny w paradygmacie sieciowym, Warszawa: Wydaw. SBP 2010, 2011; eadem, Kategoryzacja. Studium z teorii języków informacyjno-wyszukiwawczych, Warszawa: Wydaw. SBP 2000; Opracowanie rzeczowe. Praca zbiorowa pod red. J. Woźniak-Kasperek, Piotra Bierczyńskiego, Warszawa: Wydaw. SBP 2006.

36 Jakość ustug bibliotecznych $w$ spoleczeństwie informacyjnym. Praca zbiorowa pod red. Joanny Kamińskiej i Beaty Żołędowskiej-Król, Warszawa: Wydaw. SBP 2009.

37 Ewa GŁOWACKA, Kultura oceny w bibliotekach. Obszary, modele i metody badań jakości zasobów oraz ustug biblioteczno-informacyjnych, Toruń: Wydaw. Naukowe Uniwersytetu Mikołaja Kopernika 2015.

38 Anna MIERZECKA-SZCZEPAŃSKA, Badania zachowań informacyjnych, Warszawa: Wydaw. SBP 2013; Barbara KAMIŃSKA-CZUBAŁA, Zachowania informacyjne $w$ życiu codziennym. Informacyjny świat pokolenia Y, Warszawa: Wydaw. SBP 2013.

39 Marzena ŚWIGOŃ, Polska Skala Niepokoju zwiazanego z korzystaniem z biblioteki. Wyniki badań, Przegląd Biblioteczny (79) 2011, z. 2, s. 231-243; eadem, Dzielenie się wiedza i informacją. Specyfika nieformalnej komunikacji w polskim środowisku akademickim, Olsztyn: Wydaw. Uniwersytetu Warmińsko-Mazurskiego 2015.

40 M. WOJCIECHOWSKA, Studium zarzadzania niematerialnymi zasobami organizacyjnymi bibliotek, Gdańsk: Wydaw. Uniwersytetu Gdańskiego 2014; Zarządzanie zasobami niematerialnymi bibliotek $w$ społeczeństwie wiedzy. Red. M. Wojciechowska, Warszawa: Wydaw. SBP 2016.

Roczniki Biblioteczne 60, 2016

(C) for this edition by CNS 
umiejętności i predyspozycji kandydatów do zawodu w ocenie pracodawców ${ }^{41}$ oraz kierownictwa bibliotek ${ }^{42}$, a także jakości i kultury edukacyjnej, etyki zawodu, profilowania nowych kierunków studiowania - atrakcyjnych dla przyszłych bibliotekarzy i bibliotekoznawców ${ }^{43}$.

Zagadnienia etyki w pracy bibliotekarza podejmował Z. Żmigrodzki, a dyskusja wokół Patologii bibliotecznej (Katowice 1998) zaowocowała powołaniem zespołu i w efekcie opracowaniem Kodeksu etyki bibliotekarza i pracownika informacji naukowej (Warszawa 2005) ${ }^{44}$.

Sprawy kształcenia bibliotekarzy, misji i wizerunku bibliotekarza od „kelnera wiedzy” do „brokera i architekta informacji”"45, a także etyki zawodu systematycznie pojawiają się na łamach czasopism bibliotekarskich, były też przedmiotem wielu badań ${ }^{46}$.

Ważną rolę w przygotowaniu praktyków zawodu, a także współtworzeniu polityki bibliotecznej w Polsce odgrywają ośrodki kształcenia na poziomie akademickim. Cykliczne badania dotyczące edukacji na poziomie wyższym zainicjowano w „,szkole krakowskiej” dzięki Marii Kocójowej, głos w tej sprawie wielokrotnie zabierała Maria Próchnicka ${ }^{47}$, obecnie badania te są kontynuowane przez Małgorzatę Jaskowską, Agnieszkę Korycińską-Huras, Monikę Krakowską, Sabinę Cisek oraz młodsze pokolenie badaczy. Problematykę przemian modelu kształcenia w zakresie bibliologii i informatologii podjęła Stanisława Kurek- Kokocińska podczas uroczystości siedemdziesięciolecia działalności pierwszego w Polsce łódzkiego ośrodka akademickiego kształcenia bibliotekarzy. Zagadnienia te należą

41 Małgorzata JASKOWSKA, Agnieszka KORYCIŃSKA-HURAS, Maria PRÓCHNICKA, Wiedza i umiejętności zawodowe bibliotekarzy i pracowników informacji. Badanie oczekiwań pracodawców, [w:] Nowoczesna biblioteka..., s. 87-132.

42 E. GŁOWACKA, op. cit.

43 Edukacja z zakresu bibliotekoznawstwa i informacji naukowej na poziomie wyższym w Polsce. Status i przyszłość. Red. Maria Kocójowa, Kraków: Polskie Tow. Bibliologiczne 1995; także prace M. Próchnickiej i M. Jaskowskiej.

${ }^{44}$ Kodeks etyki bibliotekarza i pracownika informacji naukowej opracowali Sabina Cisek, Zdzisław Gębołyś, Henryk Hollender, Artur Jazdon pod kierownictwem Barbary Sosińskiej-Kalaty, w składzie zespołu oceniającego znaleźli się: M. Drzewiecki, B. Howorka, K. Migoń, H. Tadeusiewicz, J. Wojciechowski, J. Wołosz i Z. Żmigrodzki.

${ }^{45}$ Stanisław SKÓRKA, Architekt informacji - kreator przestrzeni informacyjnych, Przegląd Biblioteczny 2011, z. 1, s. 47-61.

46 Zawód bibliotekarski, Przegląd Biblioteczny (55) 1987, z. 3-4, s. 243-397, prezentujący wypowiedzi T. Zarzębskiego, J. Kołodziejskiej, J. Ćwiekowej, J. Dunina, M. Pidłypczak-Majerowicz, Z. Żmigrodzkiego; cyk1 „Polemiki” na łamach Bibliotekarza (1988); H. WIĘCKOWSKA, Akademickie ksztatcenie bibliotekarzy. Zarys historyczny, Warszawa: Wydawnictwa Akcydensowe 1979 .

47 M. PRÓCHNICKA, Standardy kształcenia i akredytacja kierunku „Informacja naukowa i bibliotekoznawstwo", [w:] Przyszłość bibliotek w Polsce..., s. 110-121; Studia z zakresu informacji naukowej i bibliotekoznawstwa w Polsce wobec Europejskich i Krajowych Ram Kwalifikacji, s. 229-245.

Roczniki Biblioteczne 60, 2016

(C) for this edition by CNS 
obecnie do szczególnie istotnych $\mathrm{w}$ dyskusji na temat kreowania nowoczesnego modelu bibliotek i bibliotekarstwa - przede wszystkim zarządzania zasobem $\mathrm{i}$ informacją oraz wizerunkiem, przestrzenią fizyczną i wirtualną wysokiej jakości. Priorytetowym zadaniem jest projektowanie atrakcyjnej i szerokiej oferty studiów z zakresu bibliologii i informatologii, a zwłaszcza wdrażanie wielu nowych kierunków zamiast lub równolegle z tradycyjną ,informacją naukową i bibliotekoznawstwem”, m.in. „informacja w instytucjach e-społeczeństwa”, „zarządzanie informacją" i ,architektura informacji”. Problem pojawiania się nowych kierunków na studiach bibliotekoznawczych dostrzegał już D. Kuźmina ${ }^{48}$, a proces ten podlega dalszej intensyfikacji. Organizowanie procesu dydaktycznego wysokiej jakości, standaryzacji i systematycznej reorganizacji zgodnie z zasadami Krajowych Ram Kwalifikacyjnych uwzględniających efekty kształcenia w obszarze wiedzy, umiejętności i kompetencji społecznych wynika z deklaracji bolońskiej (1999) i budowania europejskiego obszaru szkolnictwa wyższego.

Od wielu lat w literaturze bibliotekarskiej obecne są zagadnienia budownictwa bibliotecznego i projektowania przestrzeni bibliotek, ich aranżacji i designu. Począwszy od fundamentalnej publikacji Zbigniewa Cudnika Skarbnice wiedzy. Studium budownictwa bibliotek (Warszawa 1980), do grona autorów należą Ewa Kobierska-Maciuszko, Danuta Konieczna, Tomasz Kruszewski, Anna Walczak ${ }^{49}$. Pewnym podsumowaniem obecnego etapu dyskusji jest artykuł (,esej filozoficzny") Wertykalność biblioteki — od sacrum i strażnicy do ikony marketingu Tomasza Kruszewskiego ${ }^{50}$.

Analiza piśmiennictwa naukowego dotyczącego „nauki o bibliotece” przyjąć może również porządek zgodny z typologią bibliotek.

1) Zagadnienia dotyczące problematyki bibliotekarstwa naukowego — przede wszystkim misji, organizacji i funkcji Biblioteki Narodowej, bibliotek akademickich szkół wyższych państwowych i prywatnych, bibliotek sieci Polskiej Akademii Nauk i jej placówek zagranicznych oraz towarzystw naukowych, a także bibliotek organizowanych w jednostkach badawczo-rozwojowych podejmowane były, i są nadal, przez wielu badaczy. Publikacje dotyczą przede wszystkim bogactwa zasobów, zasad organizowania i udostępniania (także cyfrowego) kolekcji, specyfiki wybranych typów dokumentów, roli w inicjowaniu nowych rozwiązań normalizacyjnych i inicjatyw bibliotekarskich, również oczekiwań i zachowań informacyjnych odbiorców — klientów informacji, a nawet poziomu ich satysfakcji.

48 D. KUŹMINA, Ksztatcenie w zakresie informacji naukowej i bibliotekoznawstwa w Polsce - nowe kierunki, [w:] Nowoczesna biblioteka..., s. 133-141.

49 Danuta KONIECZNA, Nowe trendy $w$ architekturze i organizacji przestrzeni $w$ bibliotekach polskich, [w:] Nowoczesna biblioteka...; Tomasz KRUSZEWSKI, Przestrzenie biblioteki. O symbolicznej, fizycznej i społecznej obecności instytucji, Toruń: Wydaw. Naukowe Uniwersytetu Mikołaja Kopernika 2012; Anna WALCZAK, Projektowanie bibliotek, [w:] Bibliotekarstwo..., s. 679-690.

50 Przegląd Biblioteczny (84) 2016, z. 1, s. 46-64. 
W nielicznych pracach ukazywano tę problematykę w sposób kompleksowy, m.in. w publikacjach Ryszarda Przelaskowskiego i Leona Łosia ${ }^{51}$; „Przegląd Biblioteczny” (1969, z. 2/3) w całości był prezentacją zagadnień dotyczących placówek naukowych, m.in. bibliotek lekarskich autorstwa ówczesnego dyrektora Głównej Biblioteki Lekarskiej, Stanisława Konopki, czy księgozbiorów towarzystw naukowych. Wydawano informatory bibliotek sieci PAN i towarzystw naukowych (1969), analizowano zasób placówek zagranicznych ${ }^{52}$.

Wiele prac, sprawozdań i raportów dotyczy roli Biblioteki Narodowej w kształtowaniu polityki bibliotecznej w kraju, osiągnięć w podejmowanych badaniach w poszczególnych jej instytutach, zakładach i działach. Publikowano katalogi, informacje na temat historii placówki, a zagadnienia dotyczące „stanu i oczekiwań" wobec książnicy narodowej były przedmiotem rozważań w czasopismach $^{53}$ - także w wydawnictwach BN - m.in. „Roczniku Biblioteki Narodowej" (Warszawa 1965-). Publikowane są również wyniki badań dotyczące zadań priorytetowych, realizowanych w bibliotekach naukowych, m.in. z zakresu kreowania i inicjowania nowych rozwiązań dotyczących polityki gromadzenia i kształtowania kolekcji, zarządzania finansami i informacją (wiedzą) w aspekcie redagowania, kodowania (opracowanie formalne, rzeczowe: JHP BN, KABA, UKD) i transmisji informacji, zarządzania personelem - niematerialnymi zasobami bibliotek. Interesujące publikacje i materiały konferencyjne $\mathrm{z}$ dyskusji dotyczą wizerunku i aspektów przestrzeni fizycznej (budownictwo, aranżacja wnętrz) oraz bibliotek wirtualnych, przeprowadzanych audytów potrzeb i satysfakcji użytkowników - prosumentów informacji. Współpraca i kooperacja bibliotek, rola i misja dla środowiska naukowego, a zwłaszcza inicjowanie i wdrażanie nowych rozwiązań modelowych — Biblioteka 2.0, 3.0, Second Life, modelu hybrydowego i partycypacyjnego, zasad kooperacji i współpracy m.in. w organizowaniu bibliotek cyfrowych ${ }^{54}$ — oraz intensywne i systematyczne prace normalizacyjne należą

51 Ryszard PRZELASKOWSKI, Biblioteki naukowe w Polsce. Zarys problematyki, Warszawa: Państwowy Ośrodek Kształcenia Koresp. Bibliotekarzy 1958; Leon ŁOŚ, Biblioteki naukowe, Wrocław: Zakład Narod. im. Ossolińskich 1980.

52 M.in. L. ŁOŚ, Biblioteki Polskiej Akademii Nauk. Zarys ksztaltowania sieci i stan aktualny, Wrocław: Zakład Narod. im. Ossolińskich 1973 (2. wyd. 1974); Biblioteki polskie za granica. Przeszłość $i$ współczesność. Red. Maria Kalczyńska, Danuta Sieradzka, Katowice: Wydaw. Uniwersytetu Śląskiego 2007.

53 Marek SKWARNICKI, Zarys rozwoju koncepcji i organizacji Biblioteki Narodowej $w$ Warszawie, [w:] Zzagadnień teorii i praktyki bibliotekarskiej. Studia poświęcone pamiẹci Józefa Grycza. Red. Bogdan Horodyski, Wrocław: Zakład Narod. im. Ossolińskich 1961; Biblioteka Narodowa - stan i oczekiwania, Przegląd Biblioteczny (52) 1984, z. 3-4, s. 267-442: w numerze opublikowano wypowiedzi Z. Gacy-Dąbrowskiej, J. Wołosza, J. Kołodziejskiej, Mirosławy Kocięckiej, Janiny Pelcowej, B. Sordylowej, Z. Żmigrodzkiego.

${ }^{54}$ Biblioteki cyfrowe. Red. Małgorzata Janiak, Monika Krakowska, Maria Próchnicka, Warszawa: Wydaw. SBP 2012; Biblioteki cyfrowe. Projekty, realizacje, technologie. Red. Jadwiga Woźniak-Kasperek, Jerzy Franke, Warszawa: Wydaw. SBP 2007. 
do niewątpliwych osiągnięć całego środowiska bibliotekarzy naukowych ${ }^{55}$. Głos w sprawie aktualnych problemów bibliotek akademickich zabiera liczne grono badaczy, w tym dyrektorzy placówek: Henryk Hollender, A. Jazdon, M. Wojciechowska. Rolę bibliotek naukowych w inicjowaniu i kreowaniu nowoczesnych rozwiązań analizował m.in. Remigiusz Sapa podczas katowickiego Kongresu Kultury Książki (2012) ${ }^{56}$, publikowane są materiały z systematycznie organizowanych konferencji naukowych ${ }^{57}$.

2) Dorobek piśmienniczy w zakresie bibliotekarstwa publicznego wynika z priorytetowej zasady organizowania sieci placówek tego typu, spełniających ważną misję społeczną i funkcję kulturotwórczą, a także zadania edukacyjne i informacyjne, hobbystyczne, kompensacyjne i rekreacyjne skierowane do najszerszego grona odbiorców — od dzieci i młodzieży po seniorów. Pierwsze powojenne publikacje z tego zakresu to Bibliotekarstwo powszechne zredagowane przez Ewę Pawlikowską (Warszawa 1957-1959), publikacje Heleny Radlińskiej i Ryszarda Przelaskowskiego ${ }^{58}$. Zmiany rozporządzeń dotyczących samorządu terytorialnego, a także struktury sieci bibliotek publicznych w wyniku kolejnych zmian administracyjnych kraju również mają swoje odniesienie w literaturze przedmiotu. Ukazały się zatem prace zbiorowe, materiały z cyklicznych konferencji, m.in. dotyczące okresu transformacji bibliotek po 1989 roku oraz sytuacji przełomu wieków, w których podejmowana jest problematyka unowocześniania (w aspekcie automatyzacji) i komputeryzacji oraz oferty usług. Stan bibliotek rejestrowany jest w roczniku „Biblioteki Publiczne w Liczbach” (1971-). Obecnie istotnym wzorcem są wytyczne IFLA/UNESCO opublikowane przez Stowarzyszenie Biblio-

55 J. WOJCIECHOWSKI, Biblioteki akademickie: obszary kooperacji, Przegląd Biblioteczny (80) 2012, nr 4, s. 477-492.

56 Remigiusz SAPA, Biblioteka naukowa w integrujacym się środowisku informacyjnym człowieka, [w:] Teoretyczne zagadnienia bibliologii i informatologii. Studia i szkice. Red. Elżbieta Gondek, Katowice: Wydaw. Uniwersytetu Śląskiego 2015, s. 75-88.

57 Tradycja i nowoczesność w bibliotece naukowej XXI wieku. Red. Aneta Januszko-Szakiel, Kraków: Krakowskie Towarzystwo Edukacyjne - Oficyna Wydawnicza AFM 2012; E-nauka wyzwania dla bibliotek akademickich, Biuletyn EBIB 2012, nr 8 (135); Stan i potrzeby polskich bibliotek uczelnianych. Materiały z ogólnopolskiej konferencji naukowej, Poznań 13-15 listopada 2002, Poznań: Biblioteka Uniwersytecka 2002; Tradycja i nowoczesność bibliotek akademickich. Materiały z ogólnopolskiej konferencji naukowej, Rzeszów-Czarna, 1-3 czerwca 2005. Oprac. Ewa Bieniasz, Krystyna Serwatko, Bożena Jaskowska, Rzeszów: Biblioteka Uniwersytetu Rzeszowskiego 2005; Biblioteki naukowe w kulturze i cywilizacji. Działania i codzienność. Materiały konferencyjne, Poznań 15-17 czerwca 2005. T. 1-2. Red. Halina Ganińska, Poznań: Biblioteka Główna Politechniki Poznańskiej 2005; Biblioteki szkót wyższych w społeczeństwie wiedzy. Uwarunkowania $i$ wybrane zagadnienia. T. 1. Konteksty i uwarunkowania, t. 2. Narzędzia i formy funkcjonowania, Katowice: Uniwersytet Śląski 2010.

58 Helena RADLIŃSKA, Nasze biblioteki powszechne, [w:] Zagadnienia bibliotekarstwa i czytelnictwa, Wrocław: Zakład Narod. im. Ossolińskich 1961; Ryszard PRZELASKOWSKI, Zagadnienia teoretyczne organizacji bibliotek. Studia i szkice, Warszawa: SBP 1972. 
tekarzy Polskich w 2002 roku $^{59}$. Głos w sprawie bibliotek publicznych zabierali i zabierają bibliotekarze-praktycy, m.in. J. Kołodziejska ${ }^{60}$, J. Wołosz, L. Biliński, J. Wojciechowski - autor publikacji z zakresu bibliotekarstwa i czytelnictwa, a także obecności bibliotek w komunikacji i ich roli mediacyjnej ${ }^{61}$ — oraz Beata Żołędowska-Król ${ }^{62}$.

$\mathrm{W}$ ostatnich latach $\mathrm{w}$ wielu publikacjach zbiorowych podejmowane są aktualne problemy dotyczące bibliotekarstwa publicznego w kontekście tożsamości i kultury, ich misji oraz modelu, m.in. mediatek, megabibliotek ${ }^{63}$, metod zarządzania zasobem, struktury i specyfiki zbiorów (biblioteki komiksowe, liberatura w Artetece WBP Krakowie), oferty usług i form aktywności dla środowiska lokalnego, budownictwa bibliotecznego i aranżacji wnętrz ${ }^{64}$. W ramach sieci organizowane są oddziały książki mówionej, filie szpitalne, placówki więzienne i biblioteki terapeutyczne. Dużą rolę w inicjowaniu czytelnictwa odgrywają oddziały dla dzieci i młodzieży: opublikowano wzorce zagraniczne, a w pracach autorstwa Barbary Białkowskiej, Grażyny Lewandowicz, Krystyny Materskiej, Bronisławy Woźniczki-Paruzel prezentowana jest działalność placówek tego typu ${ }^{65}$, dodatkowo ukazują się analizy dotyczące wyborów lekturowych m.in. autorstwa Grażyny Straus i Katarzyny Wolff, Michała Zająca, Marioli Antczak i zespołu „szkoły

59 Działalność bibliotek publicznych. Wytyczne IFLA/UNESCO, Warszawa: Wydaw. SBP 2002; Dzieci, młodzież - Internet - biblioteka. Wytyczne IFLA Sekcji Bibliotek dla Dzieci i Młodzieży. Red. Grażyna Lewandowicz-Nosal, Elżbieta Barbara Zybert, Warszawa: Wydaw. SBP 2009.

60 J. KOŁODZIEJSKA, Biblioteki publiczne. Gtówne kierunki rozwoju, Warszawa: Państwowe Wydaw. Naukowe 1972; eadem, Społeczna funkcja biblioteki publicznej, Warszawa: Biblioteka Narodowa 1976; eadem, Między teoria a praktyka bibliotekarska, Warszawa: SBP 1985; eadem, Lokalność i uniwersalność bibliotek, Warszawa: Wydaw. SBP 2000; eadem, Szerokie okno biblioteki, Warszawa: Wydaw. SBP 2006.

61 J. WOŁOSZ, SBP a standardy biblioteczne, [w:] Biblioteki publiczne wobec Unii Europejskiej, Toruń: Wydaw. Uniwersytetu Mikołaja Kopernika 2003, s. 9-23; Lucjan BILIŃSKI, Problemy i szanse bibliotek publicznych u progu XXI wieku, [w:] Biblioteki publiczne wobec..., s. 41-46.

${ }^{62}$ Beata ŻOŁĘDOWSKA-KRÓL, Wizerunek biblioteki publicznej, Katowice: Wydaw. Uniwersytetu Śląskiego 2003.

63 M.in.: Biblioteki. Tożsamość. Kultura. Red. Iwona H. Pugacewicz i Elżbieta Barbara Zybert, Warszawa: Wydaw. SBP 2013; Megabiblioteki. Wybrane tendencje w bibliotekarstwie publicznym. Red. Dorota Pietrzkiewicz, Elżbieta Barbara Zybert, Warszawa: Wydaw. SBP 2015.

64 Innowacje w bibliotekach publicznych, Biuletyn EBIB 2011, nr 5 (123); Nowoczesna biblioteka...; Przyszłość bibliotek w Polsce...

65 Biblioteki dla dzieci i młodzieży za granica, Warszawa: Biblioteka Narodowa 1971 (Zeszyty Przekładów nr 27); Barbara BIAŁKOWSKA, Biblioteka publiczna dla dzieci. Wybrane zagadnienia, Warszawa: Biblioteka Narodowa 1980; Grażyna LEWANDOWICZ-NOSAL, Biblioteki dla dzieci wczoraj i dziś, Warszawa: Wydaw. SBP 2008; Krystyna MATERSKA, Edukacyjna funkcja biblioteki publicznej w życiu młodzieży, Warszawa: SBP 1993; Bronisława WOŹNICZKA-PARUZEL, Biblioteki dla dzieci w krajach Europy Zachodniej i w Polsce - porównania i refleksje, [w:] Biblioteki publiczne wobec..., s. 47-61. 
łódzkiej"66. Wiele prac dotyczy atrakcyjnej formy mediateki dla dzieci (np. Wrocław, Warszawa, Olsztyn - Abecadło) i młodzieży (np. Planeta 11). W nielicznych publikacjach natomiast analizowane są szczegółowe zasady funkcjonowania bibliotek szpitalnych i więziennych — badania Wandy Kozakiewicz i Aleksandry Chwastek, kontynuowane przez E.B. Zybert, Magdalenę Przybysz-Stawską ${ }^{67}$, ukazują rolę biblioterapeutyczną, kompensacyjną i informacyjną realizowaną w placówkach tego typu.

Od początku lat 90 . wiele prac dotyczy obligatoryjności i zasad przystosowania bibliotek do korzystania przez osoby niepełnosprawne ${ }^{68}$, a także kształcenia i kompetencji ,bibliotekarzy klinicznych”. W ramach inicjatyw Polskiego Towarzystwa Bibliologicznego zrealizowano program „Aktualizacji kształcenia na rzecz bibliotek gminnych" (2011). Systematycznie realizowane są również atrakcyjne dla użytkowników ogólnopolskie akcje czytelnicze („Noc z Andersenem”, „Noc w bibliotece” itp.), a Program Rozwoju Bibliotek, zainicjowany przez Fundację Rozwoju Społeczeństwa Informacyjnego, od 2009 roku jest wsparciem bibliotek gminnych w pełnieniu funkcji lokalnych centrów aktywności społecznej. Celem programu „Biblioteka+” Ministerstwa Kultury i Dziedzictwa Narodowego, realizowanego przez Instytut Książki BN, jest przekształcenie bibliotek gminnych w nowoczesne centra dostępu do wiedzy, kultury i ośrodki życia społecznego. Podobny cel zakłada realizowany obecnie priorytet „Infrastruktura Bibliotek 2016-2020".

3) Dorobek piśmienniczy z zakresu bibliotekarstwa szkolnego można analizować w trzech wyraźnych fazach — do 1957 roku — daty ustanowienia zawodu bibliotekarza szkolnego, w latach 1957-1998 jako okresie kształtowania się standardów ich działalności, zwłaszcza w zakresie pracy pedagogicznej, podejmowanych rozwiązań normalizacyjnych (raport o systemie oświaty oraz o stanie bibliotek resortu oświaty i wychowania), wreszcie po konferencji nauczycieli bibliotekarzy w Kielcach (3-4 grudnia 1998 roku), rozpoczynającej dyskusję nad nowoczesnym wizerunkiem biblioteki jako szkolnego centrum informacji (SCI, ICIM — Inter-

66 Grażyna STRAUS, Modelowi sukcesorzy, indywidualiści, eklektycy, Warszawa: Biblioteka Narodowa 2005; Zbiory i zasoby informacyjne bibliotek publicznych. Red. K. Wolff. Warszawa: Wydaw. SBP 2009; Michał ZAJĄC, Promocja książki dziecięcej. Podręcznik akademicki, Warszawa: Wydaw. SBP 2006; Mariola ANTCZAK, Rola bibliotek i bibliotekarzy szkolnych w edukacji społeczeństwa informacyjnego na tle przeobrażeń oświatowych w Polsce w latach 1989-2007, Łódź: Wydaw. Uniwersytetu Łódzkiego 2010.

67 Wanda KOZAKIEWICZ, Problemy organizacji bibliotek szpitalnych, Szpitalnictwo Polskie 1972, nr 6; Aleksandra CHWASTEK, Studia nad czytelnictwem więźniów, Wrocław: Zakład Narod. im. Ossolińskich 1980; E.B. ZYBERT, Biblioteki więzienne. Zarys problematyki, Warszawa: SBP 1991; eadem, Wspótczesne biblioteki więzienne i działalność kulturalno-oświatowa w polskich zaktadach stużby więziennej, Przegląd Biblioteczny (80) 2012, z. 1, s. 3-28; Magdalena PRZYBYSZ-STAWSKA, Łódzkie biblioteki więzienne, ibidem, s. 169-180.

68 Małgorzata FEDOROWICZ, Człowiek niepetnosprawny w bibliotece publicznej, Torun: Wydaw. Naukowe Uniwersytetu Mikołaja Kopernika 2010. 
netowe Centrum Informacji Multimedialnej, SCKI — Szkolne Centrum Kultury Informacyjnej). Ważne dla innowacji wprowadzanych w polskim bibliotekarstwie szkolnym, choć późno dostrzeżone, były rozwiązania modelowe typu Media Center w USA i Francji, zaprezentowane w ramach serii „Zeszytów Przekładów” Biblioteki Narodowej69, ponieważ pozwoliły na wypracowanie nowoczesnego wizerunku biblioteki szkolnej. Wybrane publikacje z zakresu bibliotekarstwa szkolnego to m.in. Biblioteki szkolne w Polsce Ludowej ${ }^{70}$, podręczniki autorstwa Emilii Białkowskiej ${ }^{71}$, Włodzimierza Goriszowskiego - Wybrane zagadnienia bibliotekarstwa szkolnego (Warszawa 1962) i Bibliotekarz szkolny — jego cechy osobowości a efektywność działania (Katowice 1976). Duże znaczenie dla archiwizowania problematyki bibliotekarstwa szkolnego i publikowania dokumentacji źródłowej miały prace Heleny Falkowskiej — zwłaszcza $Z$ dziejów polskich bibliotek szkolnych (Warszawa 1966). Nowoczesny typ podręcznika zaproponowany przez Jadwigę Andrzejewską kontynuowała Danuta Saniewska, ukazywały się także materiały pokonferencyjne, m.in. cykl spotkań kieleckich pod redakcją Henryka Suchojada $^{72}$. Prace dokumentujące stan oraz kierunki rozwoju bibliotek szkolnych i pedagogicznych w kontekście innowacji światowych prezentował Marcin Drzewiecki ${ }^{73}$, przytaczając Raport o stanie oświaty PRL oraz publikacje Czesława Kupisiewicza, Bogdana Suchodolskiego, Wincentego Okonia ${ }^{74}$, nato-

69 Biblioteki szkolne za granica, Warszawa: Biblioteka Narodowa 1980 (Zeszyty Przekładów $\mathrm{nr} 41)$.

70 Biblioteki szkolne w Polsce Ludowej. Red. Feliks Popławski. T. 1-2, Warszawa: Państwowe Zakłady Wydawnictw Szkolnych 1966-1969.

71 M.in. Emilia BIAŁKOWSKA, Stefan BZDĘGA, Organizacja i metody pracy bibliotek szkolnych, Warszawa: Państwowy Ośrodek Kształcenia Koresp. Bibliotekarzy 1966.

72 Danuta SANIEWSKA, Vademecum wspótczesnego nauczyciela bibliotekarza, Warszawa: Agencja „Sukurs” 2011 (także wydania wcześniejsze); Biblioteka i informacja w systemie edukacji. Materiały konferencji naukowej Kielce, 3-4 grudnia 1998. Red. H. Suchojad, Kielce: Biblioteka Główna Wyższej Szkoły Pedagogicznej im. Jana Kochanowskiego 1999; Współczesne standardy bibliotek szkolnych w zreformowanym systemie oświaty. Zob. Biblioteki szkolne centrum informacji multimedialnej i internetowej. Biuletyn EBIB 2000, nr 9 (18).

73 Marcin DRZEWIECKI, Biblioteki szkolne i pedagogiczne w Polsce. Rola w procesie dydaktycznym i miejsce w krajowej sieci biblioteczno-informacyjnej, Warszawa: Wydaw. Uniwersytetu Warszawskiego 1991; także inne, m.in. Współczesna biblioteka szkolna, Warszawa: Biblioteka Narodowa 1980; Biblioteka i informacja w środowisku współczesnej szkoty, Warszawa: SBP 2001; Edukacja biblioteczna i informacyjna w polskich szkołach, Warszawa: Wydaw. SBP 2005; Biblioteka w spoleczeństwie informacyjnym. Edukacja, informacja, media. Red. M. Drzewiecki, M. Majewska, Warszawa: Centrum Edukacji Bibliotekarskiej, Informacyjnej i Dokumentacyjnej im. Heleny Radlińskiej 2005; Wspótczesne aspekty funkcjonowania bibliotek szkolnych i pedagogicznych $w$ dydaktyce $i$ wychowaniu. Problemy badawcze, Przegląd Biblioteczny (74) 2006, z. 3, s. 297-301.

${ }^{74}$ Raport o stanie oświaty PRL, Warszawa 1973; Raport o stanie bibliotek resortu oświaty $i$ wychowania. Red. A. Niemczykowa, Warszawa: Ministerstwo Oświaty i Wychowania 1980; Czesław KUPISIEWICZ, Przemiany edukacyjne w świecie na tle raportów oświatowych, Warszawa: Wiedza Powszechna 1978; Model wyksztatconego Polaka. Red. B. Suchodolski, Wrocław: Zakład 
miast w publikacji Funkcjonowanie bibliotek szkolnych $w$ Polsce pod redakcją Jerzego Jarowieckiego (Kraków 1991) zamieszczona została analiza i ocena księgozbiorów szkolnych oraz propozycja lektur i oferta wydawnictw informacyjnych, dokonana przez Józefa Szockiego ${ }^{75}$. Aktualnym wzorem dla bibliotekarzy szkolnych są wytyczne IFLA/UNESCO wydane przez SBP w $2003 \mathrm{roku}^{76}$, a także publikacje Bogumiły Staniów, Hanny Batorowskiej, Barbary Kamińskiej-Czubały ${ }^{77}$ oraz wydawnictwa redagowane przez E.B. Zybert ${ }^{78}$.

Duże znaczenie dla integrowania środowiska nauczycieli bibliotekarzy oraz ich systematycznego rozwoju naukowego i zawodowego ma działalność Towarzystwa Nauczycieli Bibliotekarzy Szkół Polskich — m.in. organizowanie sesji naukowych ${ }^{79}$ - a także czasopisma — przede wszystkim "Biblioteka w Szkole” (Warszawa 1991-), „Biblioteka - Centrum Informacji” (2008-), „Biblioteka szkolne centrum informacji. Czasopismo dla nauczycieli bibliotekarzy” (Warszawa 2008-).

Ważnym zagadnieniem była i jest nadal sprawa kompetencji i aktualizacji kształcenia nauczycieli bibliotekarzy łączących uprawnienia pedagogiczne z umiejętnością zarządzania zasobem. Sprawie tej poświęcono wiele uwagi na łamach czasopism ${ }^{80}$.

Piśmiennictwo dotyczące bibliotek pedagogicznych realizujących zadania wspierania procesu kształcenia i doskonalenia nauczycieli, a także instruktażu i pomocy bibliotekom szkolnym w niebawem dziewięćdziesięciopięcioletnim ich istnieniu świadczy o znaczącej ich roli. Wśród wydawnictw powojennych wymienić można informatory ${ }^{81}$ i monografie jubileuszowe wojewódzkich bibliotek pedagogicznych oraz wybranych placówek filialnych, materiały metodyczne i kon-

Narod. im. Ossolińskich 1980; Wincenty OKOŃ, Szkoła współczesna. Przemiany i tendencje rozwojowe, Warszawa: Książka i Wiedza 1979.

75 Z zagadnień ksztaltowania się księgozbiorów bibliotek szkół podstawowych.

76 Biblioteki szkolne. Wytyczne IFLA/UNESCO. Oprac. Tove Pemmer Saetre, Glenys Willars, Warszawa: Wydaw. SBP 2003.

77 Bogumiła STANIÓW, Biblioteka szkolna dzisiaj, Warszawa: Wydaw. SBP 2012; Hanna BATOROWSKA, B. KAMIŃSKA-CZUBAŁA, Szkolne Centrum Informacji, Kraków: Wydaw. Zakonu Pijarów 2002; H. BATOROWSKA, Kultura informacyjna w perspektywie zmian w edukacji, Warszawa: Wydaw. SBP 2009.

${ }^{78}$ Ksiązka i biblioteka w środowisku edukacyjnym. Red. E.B. Zybert, Warszawa: Wydaw. SBP 2002; Ksiązka, biblioteka, informacja w kręgu kultury i edukacji. Red. E.B. Zybert, Dorota Grabowska, Warszawa: Wydaw. SBP 2008.

79 M.in. Biblioteka szkolna w cyfrowej rzeczywistości. Sesja naukowa TNBSP oraz serwisu Elektroniczna Biblioteka Pedagogiczna SBP, Warszawa 26 września 2013 r.; zob. też Biblioteki szkolne, Biuletyn EBIB 2013, nr 7 (143).

80 M.in. Kształcenie uniwersyteckie pracowników bibliotek szkolnych, Przegląd Biblioteczny (53) 1985 , z. 2, s. 165-238.

81 Biblioteki pedagogiczne $w$ Polsce. Informator bibliotek pedagogicznych w roku szkolnym 2003/2004, Warszawa: CODN 2003. 
ferencyjne ${ }^{82}$, opracowany został projekt systemu informacyjno-bibliotecznego dla resortu oświaty i wychowania oraz powołania Centralnej Biblioteki Pedagogicznej ${ }^{83}$. Problemy związane z bieżącą i historyczną działalnością placówek, współpracą z innymi bibliotekami oraz środowiskiem ${ }^{84}$, zarządzaniem zasobem ukazują się na łamach większości czasopism bibliotekarskich, a także „Kwartalnika Pedagogicznego”, „Głosu Nauczycielskiego”, „Chowanny”"85.

4) Problematyka organizowania bibliotek fachowych i zakładowych, archiwizowania i zasad opracowania gromadzonych w nich specyficznych zasobów (dokumenty normalizacyjne, patenty, literatura firmowa), wprowadzania atrakcyjnych form udostępniania (np. obieg czasopism) była przedmiotem analiz R. Przelaskowskiego, J. Ratajewskiego, opracowano wielokrotnie wznawiany podręcznik Biblioteka fachowa Edwarda Assbury'ego, Jadwigi Czarneckiej i Tadeusza Bruszewskiego (wyd. 5 zaktualizowane, Warszawa 1978), Piotr Bierczyński analizował problemy bibliotek zakładowych ${ }^{86}$. Nową jakością bibliotek fachowych jest m.in. model nowoczesnych, znakomicie zarządzanych i finansowanych bibliotek kancelarii prawniczych ${ }^{87}$.

Piśmiennictwo dotyczące szerokiej i zasobnej grupy bibliotek kościelnych do 1989 r. było rozproszone. Zadania rejestrowania wybranych problemów dotyczących historycznych zasobów oraz polityki ich udostępniania, retrokonwersji oraz digitalizacji podjęto w czasopiśmie „Archiwa, Biblioteki i Muzea Kościelne” (Lublin 1959-), od 1995 roku także w „FIDES Biuletyn Bibliotek Kościelnych”. Ukazują się opracowania na temat bibliotek kościelnych i klasztornych, propozy-

82 M.in. I Krajowa Konferencja Bibliotekarzy Bibliotek Szkolnych i Pedagogicznych, Warszawa, 25 kwietnia 2007 r., Wrocław: Instytut Badań w Oświacie 2007; Biblioteki pedagogiczne w społeczeństwie informacyjnym. Materiały konferencyjne. Red. Janusz Kostynowicz, Ewa Wroczyńska, Warszawa: Wydawnictwa CODN 2005; Biblioteki pedagogiczne wobec wyzwań wspótczesnej oświaty. Materiały konferencji naukowej Kalisz 11-12 maja 2006. Red. Danuta Wańka, Kalisz: Kaliskie Tow. Przyjaciół Nauk 2008.

${ }^{83}$ M. DRZEWIECKI, op. cit., s. 262-282; Maria DEMBOWSKA, System biblioteczno-informacyjny resortu oświaty i wychowania, Aktualne Problemy Informacji i Dokumentacji 1983, nr 1 , s. 14-18.

84 Wojewódzkie biblioteki pedagogiczne w krajowej sieci wspólpracy. Ogólnopolska konferencja dyrektorów WBP w Sulejówku 3-4 października 2002. Oprac. Janusz Kostynowicz, Robert Miszczuk. Warszawa: Wydaw. CODN 2002.

85 Hanna LANGER, Agnieszka BAJOR, Modele wspótpracy bibliotek szkolnych i pedagogicznych na rzecz edukacji ustawicznej nauczycieli bibliotekarzy, Chowanna 2009, tom jubileuszowy, s. 111-126.

${ }^{86}$ R. PRZELASKOWSKI, Biblioteki techniczne w Polsce, Warszawa: SBP 1956; Edward ASSBURY, Tadeusz BRUSZEWSKI, Jadwiga CZARNECKA, Praca biblioteki fachowej, Warszawa: Państwowy Ośrodek Kształcenia Korespondencyjnego Bibliotekarzy 1973; J. RATAJEWSKI, Biblioteki naukowe i fachowe oraz ośrodki informacji naukowo-technicznej w komunikacji społecznej, Katowice: Uniwersytet Śląski 1982; P. BIERCZYŃSKI, Biblioteki zakładowe. Stan obecny i perspektywy zmian, Przegląd Biblioteczny (57) 1989, z. 2, s. 125-135.

87 Biblioteki fachowe, Biuletyn EBIB 2000, nr 11 (11). 
cje typologii bibliotek kościelnych Waldemara Żurka ${ }^{88}$, prace Ludwika Grzebienia, Mieczysława Patera. Duże znaczenie mają również publikowane materiały konferencyjne oraz analiza wybranych typów dokumentów ${ }^{89}$, katalogi i inwentarze bibliotek, opisy kolekcji w wybranych bibliotekach kościelnych, badania zasobów i dyskusje na temat roli bibliotek parafialnych ${ }^{90}$.

Istotną rolę w diagnozowaniu i ocenie, lecz przede wszystkim w kreowaniu przyszłości dyscypliny i inicjowaniu nowych kierunków badań spełniają czynni zawodowo bibliotekarze praktycy, w tym dyrektorzy wielu placówek, a także teoretycy związani z ośrodkami kształcenia. Ważne dla rozwoju badań są również intensywne działania przedstawicieli związków, towarzystw i organizacji bibliotekarskich, zwłaszcza Stowarzyszenia Bibliotekarzy Polskich, Towarzystwa Nauczycieli Bibliotekarzy Szkół Polskich, Polskiego Towarzystwa Bibliologicznego, w dużym stopniu również Polskiego Towarzystwa Informacji Naukowej. Efektami kolejnych spotkań w ramach Forum SBP są drukowane materiały ze zjazdów bibliotekarzy ${ }^{91}$, pokonferencyjne, np. publikacja Przyszłość bibliotek $w$ Polsce (2007, wyd. 2008), będąca edytorskim efektem VI Forum SBP. Duże znaczenie dla środowiska bibliotekarskiego mają publikowane materiały konferencyjne SBP, będące diagnozą i próbą perspektywicznej oceny, jak Nowoczesna biblioteka (2009).

Dorobek piśmienniczy z zakresu nauki o bibliotece wspomaga kadrę biblioteczną, służy również kształceniu przyszłych bibliotekarzy i pracowników informacji. Literatura dotycząca zagadnień bibliotekoznawstwa i bibliotekarstwa podręczniki i syntezy, kompendia, normy i wskaźniki, sprawozdania — stanowi ważny element procesu kształcenia i doskonalenia zawodowego. Najważniejszą rolę pełni obecnie Wydawnictwo SBP, które jest największą oficyną wydawniczą środowiska bibliotekarskiego, wydaje siedem serii (m. in. „Nauka, Dydaktyka, Praktyka” - ponad 170 tytułów, „FOrmaty-KArtoteki”, „Propozycje i Materiały") wiele tytułów publikuje również poza seriami. Materiały szkoleniowe ukazywały się również jako wydawnictwa Centrum Ustawicznego Kształcenia Bibliotekarzy, Centrum Edukacji Bibliotekarskiej, Informacyjnej i Dokumentacyjnej, w latach wcześniejszych w seriach „Materiały Szkoleniowe CINTE” i „Materiały Metodyczne SINTO”.

88 Biblioteki kościelne i klasztorne w Polsce. Historia i współczesność. Red. Henryk Olszar, Bogumiła Warząchowska, Katowice: Księgarnia św. Jacka 2009; Biblioteki kościoła katolickiego w Polsce. Informator. Oprac. Waldemar Witold Żurek, Kielce: „Jedność” 2005.

89 M.in. Bolesław KUMOR, Mikrofilmowanie zbiorów kościelnych, Warszawa: 1978; Rękopisy w zbiorach kościelnych. Oprac. Tomasz Makowski, Warszawa: Biblioteka Narodowa 2014.

90 D. KUŹMINA, Biblioteki parafialne — niedostrzegane instytucje współczesnej kultury. Projekt badań, [w:] Biblioteki w systemie kultury jednoczacej się Europy. Red. Michał Zając, Elżbieta Barbara Zybert, Warszawa: Wydaw. SBP 2007; Biblioteki kościelne i teologiczne, EBIB 2002, nr 6.

91 Biblioteki polskie dziś i jutro, Przegląd Biblioteczny (56) 1988, z. 3-4, będący w całości prezentacją materiałów z IX Zjazdu Bibliotekarzy Polskich. 
Oferta czasopism wymaga odrębnych badań, należy jednak podkreślić naukową i opiniotwórczą, archiwizacyjną i kreatywną rolę „Przeglądu Bibliotecznego” (1927-), „Roczników Bibliotecznych” (Wrocław 1957-), „Bibliotekarza”, „Poradnika Bibliotekarza”, „Bibliothecae Nostrae” (Katowice 2005-), a także „Zarządzania Biblioteką” (Gdańsk 2010-) oraz „Biuletynu EBIB” (online 1999-). Duże znaczenie dla nauczycieli bibliotekarzy ma również miesięcznik „Biblioteka w Szkole” i „Biblioteka Centrum Informacji”. Ważnym źródłem informacji był „Informator Bibliotekarza i Księgarza” (1956-1989) oraz „Ze Skarbca Kultury” (Wrocław 1951-1991), kontynuowane obecnie jako „Czasopismo Zakładu Narodowego Imienia Ossolińskich” (Wrocław 1992-). Znaczącą rolę odgrywają czasopisma Biblioteki Narodowej, a także liczne wydawnictwa periodyczne oraz serie wydawnicze bibliotek i ośrodków kształcenia bibliotekarzy ${ }^{92}$.

$\mathrm{W}$ ramach podejmowanych badań naukowych w ośrodkach kształcenia na kierunku bibliologia i informatologia (także wspomnianych: architektura informacji, zarządzanie informacją, informacja w instytucjach e-społeczeństwa), realizowane są - kontynuowane lub inicjowane - specyficzne i charakterystyczne dla nich kierunki badawcze. Efektem prac badawczych są publikacje autorskie, materiały z konferencji naukowych będące prezentacją dorobku pracowników instytutów, zakładów i katedr, także wyniki badań młodych badaczy — doktorantów i studentów podejmujących badania w ramach Kół Naukowych. Specyfiką badań podejmowanych w Uniwersytecie Łódzkim są zagadnienia bibliotek szkolnych (prace M. Antczak) i kształcenia (prace S. Kurek-Kokocińskiej). Duże znaczenie ma opracowanie Podręcznego stownika bibliotekarza (2011) oraz Stownika pracowników ksiązki polskiej z suplementami (od 1972 roku). Na Uniwersytecie Warszawskim zagadnienia współczesnego bibliotekarstwa podejmowane są przez Elżbietę Barbarę Zybert, Barbarę Sosińską-Kalatę, Jadwigę Woźniak-Kasperek, Małgorzatę Kisilowską, Michała Zająca, Dariusza Grygrowskiego, Dariusza Kuźminę. Ośrodek wrocławski cechuje bogaty dorobek z zakresu historii książki i bibliotek (m.in. prace Kazimiery Maleczyńskiej, Zofii Gacy-Dąbrowskiej, Anny Aleksiewicz, Anny Żbikowskiej-Migoń, Krzysztofa Walczaka, Macieja Matwijowa), nauki o książce i kultury książki (Krzysztof Migoń), sztuki książki (Małgorzata Komza), współczesnego bibliotekarstwa szkolnego (Bogumiła Staniów). W krakowskim Instytucie Informacji Naukowej i Bibliotekoznawstwa UJ realizowane są badania z zakresu akademickiego kształcenia bibliotekarzy (Maria Próchnicka), bibliotekarstwa współczesnego i czytelnictwa (Jacek Wojciechowski) i historycznego (Zdzisław Pietrzyk), natomiast na Uniwersytecie Pedagogicznym przede wszystkim są to badania z historii książki i bibliotek (Jerzy Jarowiecki, Maria Konopka, Maria Pidłypczak-Majerowicz). Badania realizowane w ośrod-

92 M.in. seria „Książki o Książce”, także wydawnictwa akademickie: Acta Universitatis Wratislaviensis. Bibliotekoznawstwo (Wrocław); Folia Librorum (Łódź); Studia Bibliologiczne (Katowice, 1983-). 
ku toruńskim dotyczą m.in. biblioterapii (Bronisława Woźniczka-Paruzel), jakości usług w bibliotekach (Ewa Głowacka), książki dawnej i współczesnej (Iwona Imańska, Jacek Gzella, Janusz Tondel), przestrzeni biblioteki (Tomasz Kruszewski), wybranych zagadnień obsługi osób niepełnosprawnych (Małgorzata Fedorowicz). Na Uniwersytecie Śląskim w kręgu zainteresowań wielu pracowników znajduje się bibliotekarstwo współczesne (Joanna Kamińska, Jolanta Szulc, Beata Żołędowska-Król, Anna Tokarska), problematyka bibliotek w systemie kultury (Teresa Wilkoń), historia bibliotek (Maria Pawłowiczowa, Edward Różycki, Elżbieta Gondek), zagadnienia ochrony i konserwacji zbiorów bibliotecznych (Bronisław Zyska, Leonard Ogierman), obecne są badania z zakresu czytelnictwa. W Białymstoku badania dotyczące języków haseł przedmiotowych kontynuuje Jadwiga Sadowska, w Gdańsku Maja Wojciechowska podejmuje zagadnienia zarządzania zasobami niematerialnymi bibliotek.

Powojenny dorobek w zakresie kształtowania się bibliotekoznawstwa jako dyscypliny, podejmowanych kierunków badawczych i inicjatyw, a także rozwiązań praktycznych w zakresie działań bibliotekarskich, opartych obecnie przede wszystkim na zasadzie współpracy i kooperacji, jest rozległy. Intensywny czas zmian i nowe kierunki rozwoju widoczne są zwłaszcza w pewnych cezurach czasowych, ulegając widocznemu nasileniu w latach 70. XX wieku, związanemu z ideą SINTO i planowaniem intensywnej działalności informacyjnej. Przyjęcie ustawy o bibliotekach z 27 czerwca 1997 roku było także ważnym etapem umożliwiającym kolejną fazę standaryzacji i normalizacji bibliotekarskiej m.in. w zakresie Narodowego Zasobu Bibliotecznego (1998, 2012). Trzeba również podkreślić znaczenie systematycznego wprowadzania zmian w procesie akademickiego kształcenia bibliotekarzy i pracowników książki (od 2007 roku standardy kształcenia, od 2011 roku program boloński).

Prezentowany tekst, nieroszczący prawa do kompletności zwłaszcza w zakresie dorobku dotyczącego historii bibliotek, związanego z definiowaniem i odkrywaniem, często tragicznych w dziejach Polski, losów instytucjonalnych i prywatnych księgozbiorów, stanowi próbę usystematyzowania osiągnięć polskiego bibliotekoznawstwa i bibliotekarstwa okresu powojennego. Pominięto kontekst międzynarodowy, m.in. wzorce, relacje oraz wpływy teorii i praktycznych światowych rozwiązań bibliotekarskich (USA, Unia Europejska) na koncepcje i rozwiązania stosowane w polskim środowisku teoretyków i praktyków zawodu ${ }^{93}$, nie włączono publikacji dotyczących rejestrowania i ochrony księgozbiorów oraz bibliotek prywatnych.

Prezentując dorobek piśmienniczy, z konieczności dokonano jego wyboru, a analizując publikacje całościowe, syntetyczne, podręczniki i kompendia, sta-

93 Zob. Ewa GŁOWACKA, Główne wspótczesne kierunki badań z zakresu bibliotekoznawstwa na świecie, [w:] Przyszłość bibliotek w Polsce..., s. 76-81. 
rano się ukazać kluczowe dla dyscypliny rozważania teoretyczne i rozwiązania praktyczne.

Bibliotekoznawstwo polskie znajduje się w fazie dokonywania pewnych podsumowań, na etapie łączenia go i włączania w zakres badań informatologicznych, a tendencja ta od dawna widoczna jest także w modyfikacji nazw dawnych instytutów bibliotekoznawstwa i informacji naukowej (często jako informacji naukowej i bibliotekoznawstwa, niekiedy uzupełnionych o studia bibliologiczne lub bibliologię). Bibliotekoznawca jest uważnym obserwatorem zmian dokonujących się w przestrzeni informacyjnej oraz w relacji biblioteka-odbiorca i architektem wysokiej jakości usług, także informacyjnych, wynikających z oczekiwań użytkowników.

Okazją do stawiania pytań o przyszłość dyscypliny stała się również jubileuszowa konferencja naukowa siedemdziesięciolecia działalności „szkoły łódzkiej”94 — pierwszego ośrodka akademickiego kształcenia bibliotekarzy w powojennej Polsce, a także jubileusz sześćdziesięciolecia Instytutu Informacji Naukowej i Bibliotekoznawstwa Uniwersytetu Wrocławskiego.

\section{ANNA TOKARSKA}

\section{THE POST-WAR ACHIEVEMENTS OF POLISH SCHOLARSHIP IN THE HISTORY AND THEORY OF LIBRARY SCIENCE}

\section{Summary}

The author of the paper explores the development of the concept of Polish post-war library science as an academic discipline and demonstrates the wealth of achievement in librarianship studies. Theoretical reflections and the on-going discussion about the scope of library science provide a background for a presentation of practical solutions applied in the work of libraries. The author presents library science concepts as well as authors of important publications contributing to the development of the discipline, practical librarian tasks and academic training of librarians. In addition, she analyses librarianship achievements with regard to characteristic, statutory tasks and functions of libraries as well as typology, showing their significance to librarianship practice in Poland and to the quality of academic training of librarians. There is also a brief description of the profile of the librarianship curriculum at the leading university-level institutions providing education to librarians.

KEY WORDS: library science, theory of library science, history of library science, librarianship, academic training of librarians

94 1945-2015 r., efektem konferencji będzie planowana publikacja Stanisławy Kurek-Kokocińskiej na temat przemian studiów bibliotekoznawczych w powojennej Polsce. 